\title{
MicroRNA-30a-lysyl oxidase axis in aortic dissection pathogenesis
}

\author{
Ming-Sing Si, MD \\ From the Section of Pediatric Cardiovascular Surgery, Department of Cardiac Surgery, University of Michigan, \\ Ann Arbor, Mich. \\ Disclosures: Author has nothing to disclose with regard to commercial support. \\ Received for publication Aug 12, 2017; accepted for publication Aug 19, 2017; available ahead of print Sept 15, \\ 2017. \\ Address for reprints: Ming-Sing Si, MD, 11-735 C.S. Mott Children's Hospital, SPC 4204, 1540 E Hospital Drive, \\ Ann Arbor, MI 48109-4204 (E-mail: mingsing@umich.edu). \\ J Thorac Cardiovasc Surg 2017;154:1870-1 \\ $0022-5223 / \$ 36.00$ \\ Copyright $(2) 2017$ by The American Association for Thoracic Surgery \\ http://dx.doi.org/10.1016/j.jtcvs.2017.08.046
}

Lysyl oxidase, encoded by the LOX gene (Lox in mice and rats), is an extracellular, copper-dependent enzyme that crosslinks collagen and elastin. Lysyl oxidase thus has important structural functions in load-bearing tissues in vivo. The critical function of lysyl oxidase in the cardiovascular system has also been well documented. Seminal work in the 1970s determined that a defect in the crosslinking of collagen and elastin from decreased lysyl oxidase activity was associated with the aortic aneurysm phenotype in inbred mottled mice. ${ }^{1}$ Subsequent work intentionally deleting Lox in mice revealed a causal relationship between a deficiency in lysyl oxidase and the pathogenesis of aortic aneurysm. ${ }^{2}$ More recently, genetic studies of kindreds with a strong aortopathy traits have revealed mutations in $L O X$ that interfere with its translation or protein function. ${ }^{3,4}$

Previous studies have revealed several mechanisms of $L O X$ transcriptional regulation. Hypoxia responsive elements have been identified in the promoter region of $L O X$, with $H I F 2 A$ being the most potent. ${ }^{5}$ In human granulosalutein cells, growth differentiation factor 8 has been shown to increase the expression of $L O X .{ }^{6}$ Advanced glycation end products can also increase the expression of $L O X$ in human aortic endothelial cells through the mitogen-activated protein kinase signaling pathway.

MicroRNAs are small noncoding RNA molecules that can fine-tune gene expression. MicroRNAs have also been shown to inhibit LOX expression. During preadipocyte maturation and differentiation in vitro, microRNA-27 was found to directly inhibit $L O X .^{8}$ In another study, microRNA-30a (miR-30a) was found to also directly target LOX expression in thyroid tissue. ${ }^{9}$ Downregulation of miR30a leads to an increase in $L O X$ expression and progression of thyroid cancer.

In this issue of the Journal, Yu and colleagues ${ }^{10}$ have identified a role for miR-30a-LOX axis in the pathogenesis of aortic dissection. First, these investigators established that miR-30a gene expression was significantly increased and that lysyl oxidase and elastin content were decreased in aorta

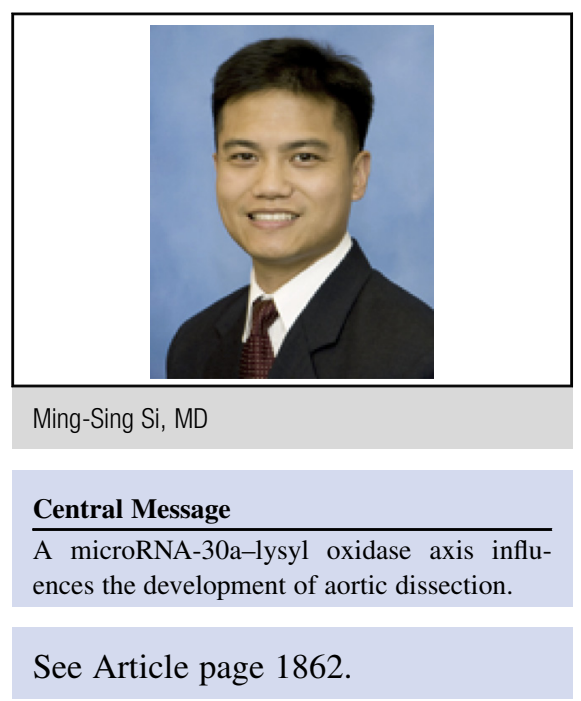

specimens from patients with aortic dissection. Through a series of in vitro experiments, the investigators then confirmed that miR-30a targeted LOX gene expression in vascular smooth muscle cells. They then performed in vivo experiments and found that enhancement of miR-30a gene expression (by treating with agonist for miR-30a) decreased lysyl oxidase and elastin in rat aortas. Rats treated with agonist for miR-30a followed by continuous angiotensin 2 infusion had acute aortic dissection develop at a greater rate than did control animals that only received angiotensin 2 . Yu and colleagues ${ }^{10}$ concluded that miR-30a overexpression can promote the development of aortic dissection by decreasing lysyl oxidase content in the aortic wall.

This study is important because it reveals an additional molecular mechanism contributing to the pathogenesis of aortic dissection. The data obtained from human and rat in vitro and in vivo studies contribute to the rigor of this study. The results of this study also suggest that miR-30a may provide a pharmaceutical target for the prevention of aortic dissection.

This study also stimulates additional questions. Does miR-30a play an important role in the development of aortic aneurysm? What are the other targets of miR-30a, and do they also contribute to the pathogenesis of aortic dissection? What drives the increased miR-30a expression in patients with aortic dissection? Finally, miR-30a is known to be protective against the progression of various cancers., ${ }^{9} 11-13$ Because of this protective effect, would (non-tissue specific) inhibition of miR-30a to prevent aortic dissection also lead to an increased risk of malignancy? 
Despite these questions, the study by Yu and colleagues ${ }^{10}$ represents a significant advance in our understanding of the pathogenesis of aortic dissection. Future research should define the factors that control miR-30a in the setting of aortic disease and determine its other relevant targets.

\section{References}

1. Rowe DW, McGoodwin EB, Martin GR, Grahn D. Decreased lysyl oxidase activity in the aneurysm-prone, mottled mouse. J Biol Chem. 1977;252:939-42.

2. Mäki JM, Rasanen J, Tikkanen H, Sormunen R, Mäkikallio K, Kivirikko KI, et al. Inactivation of the lysyl oxidase gene Lox leads to aortic aneurysms, cardiovascular dysfunction, and perinatal death in mice. Circulation. 2002; 106:2503-9.

3. Lee VS, Halabi CM, Hoffman EP, Carmichael N, Leshchiner I, Lian CG, et al. Loss of function mutation in LOX causes thoracic aortic aneurysm and dissection in humans. Proc Natl Acad Sci U S A. 2016;113:8759-64.

4. Guo DC, Regalado ES, Gong L, Duan X, Santos-Cortez RL, Arnaud P, et al. LOX mutations predispose to thoracic aortic aneurysms and dissections. Circ Res. 2016;118:928-34.

5. Wang V, Davis DA, Yarchoan R. Identification of functional hypoxia inducible factor response elements in the human lysyl oxidase gene promoter. Biochem Biophys Res Commun. 2017;490:480-5.

6. Chang HM, Fang Y, Liu PP, Cheng JC, Yang X, Leung PC. Connective tissue growth factor mediates growth differentiation factor 8-induced increase of lysyl oxidase activity in human granulosa-lutein cells. Mol Cell Endocrinol. 2016;434 186-98.

7. Adamopoulos C, Piperi C, Gargalionis AN, Dalagiorgou G, Spilioti E, Korkolopoulou P, et al. Advanced glycation end products upregulate lysyl oxidase and endothelin-1 in human aortic endothelial cells via parallel activation of ERK1/2-NF-kappaB and JNK-AP-1 signaling pathways. Cell Mol Life Sci. 2016;73:1685-98.

8. Chen SZ, Xu X, Ning LF, Jiang WY, Xing C, Tang QQ, et al. miR-27 impairs the adipogenic lineage commitment via targeting lysyl oxidase. Obesity (Silver Spring). 2015;23:2445-53.

9. Boufraqech M, Nilubol N, Zhang L, Gara SK, Sadowski SM, Mehta A, et al. miR30a inhibits $L O X$ expression and anaplastic thyroid cancer progression. Cancer Res. 2015;75:367-77.

10. Yu Y, Shi E, Gu T, Tang R, Gao S, Wang Y, et al. Overexpression of microRNA30a contributes to the development of aortic dissection by targeting lysyl oxidase. J Thorac Cardiovasc Surg. 2017;154:1862-9.

11. Liu X, Ji Q, Zhang C, Liu X, Liu Y, Liu N, et al. miR-30a acts as a tumor suppressor by double-targeting COX-2 and BCL9 in H. pylori gastric cancer models. Sci Rep. 2017;7:7113.

12. Zhang $\mathrm{Y}, \mathrm{Wu} \mathrm{Z}$, Li L, Xie M. miR-30a inhibits glioma progression and stem cell-like properties by repression of Wnt5a. Oncol Rep. 2017;38: 1156-62.

13. Singh SV, Dakhole AN, Deogharkar A, Kazi S, Kshirsagar R, Goel A, et al. Restoration of miR-30a expression inhibits growth, tumorigenicity of medulloblastoma cells accompanied by autophagy inhibition. Biochem Biophys Res Commun. 2017;491:946-52. 